\title{
A Measure of the Effectiveness and Efficiency of an M-Cinema App
}

\author{
Azham Hussain, Emmanuel O.C. Mkpojiogu, Kian Lam Tan, Kholilah Hilaluddin, \\ Shahida Jamaludin
}

\begin{abstract}
This study presents the results on the usability testing done on Golden Screen Cinema (GSC) mobile appli-cation at two sites: Polytechnic Balik Pulau, Penang and Poly-Tech College Mara (KPTM) Alor Setar, Kedah. The purpose of the testing was to elicit the overall reactions of users to the GSC mobile application with respect to the user interface, terminology and information, application capability and general impression. There were twenty volunteer participants who were recruited for the usability testing. Ten were used at Polytechnic Balik Pulau, Penang while the other ten were used at Kolej Polytech Technology Mara, Alor Setar. Of the 20 participants, 17 had no prior experiences on the use of GSC mobile application while 3 had experience on the use of GSC mobile application. The test result showed that the GSC app is both effective and efficient. Thus, indicating that the mobile application has good usability in terms effectiveness and efficiency. However, the participants' facial expressions and body language while performing tasks revealed that some of them had some challenges. Features in the GSC app, such as choosing seats and making payment made some of the participants react uneasily and with caution because of their lack of confidence as it had to do with financial matters. Based on observation, most of the participants looked nervous and felt uneasy during the session. This was so even though a brief briefing about the test was given to avoid such nervousness.
\end{abstract}

Keywords: Effectiveness, efficiency, mobile application; mobile experience; usability testing.

\section{INTRODUCTION}

Golden Screen Cinema (GSC) is an application that brings to users a listing of GSC movies with real-time show times and the option to select seats and purchase movie tickets via smartphone. GSC mobile application is available on all major mobile platforms including the iOS, Android and Windows. The application offers a revolutionary e-purchase of movie tickets and popcorn combos. E-Purchases can be made anytime, anywhere via Hong Leong Connect, Maybank2u, CIMB Clicks, PayPal, Visa Checkout, AMEX or credit cards. This ticketless option that features a QR code on the mobile phone eradicates queue and waiting time. Movie admission is a scan away at theauto-gates Five services provided by GSC mobile application were selected to be performed at the usability testing.

Revised Manuscript Received on June 22, 2019.

Azham Hussain, School of Computing, Universiti Utara Malaysia, 06010 Sintok, Kedah, Malaysia

Emmanuel O.C. Mkpojiogu, Department of Computer and Information Technology, Veritas University Abuja, Nigeria.

Kian Lam Tan, Faculty of Art, Computing and Creative Industry, Universiti Pendidikan Sultan Idris,Tanjong Malim, Perak, 35900, Malaysia

Kholilah Hilaluddin, School of Computing, Universiti Utara Malaysia, 06010 Sintok, Kedah, Malaysia

Shahida Jamaludin, School of Computing, Universiti Utara Malaysia, 06010 Sintok, Kedah, Malaysia
These include: i) download and install the GSC application, ii) login - register account on the GSC application, iii) check on GSC movie listing, iv) purchase a ticket, and v) FastTicket. The services offered through the use of the GSC web portal have proven their value by providing twenty-four hours service to users [1-7].

The usability testing was conducted in a testing room where the participants completed the five tasks that were assigned to them. The session for the usability testing was recorded and analyzed to effectively identify problems that sometimes can only be accomplished by repeated testing and with several iterations on the design. It is an excellent way to gain valuable insights into what works and what does not in the application or what is suitable or not suitable for the application [8-15].

GSC mobile application usability testing used a live version of the application located on android smartphone. One laptop was used to video record each participant and captured their faces, comments and questions. The usability testing also used screen recorder to capture every single participant's touch on the smartphone screen. This was done to capture participant who were struggling with any given task [16-25].

\section{METHODOLOGY}

Roles of participants: The table below (Table 1) shows the allocated roles and the responsibility given to facilitators and participants in the usability testing session:

Table. 1 Roles of facilitators and participants

\begin{tabular}{|l|l|}
\hline Participants & Roles \\
\hline Facilitator A & $\begin{array}{l}\text {-Pre-test briefing for participants at } \\
\text { KPTM Alor Setar } \\
\text {-Observing participants in test ses- } \\
\text { sion. } \\
\text {-Recording the test session. } \\
\text {-Conducting post-test interviews on } \\
\text { participants. }\end{array}$ \\
\hline Facilitator B & $\begin{array}{l}\text {-Pre-test briefing for participants at } \\
\text { Politeknik Balik Pulau. } \\
\text {-Observing participants in test ses- } \\
\text { sion. } \\
\text {-Recording the test session. } \\
\text {-Conducting post-test interviews on } \\
\text { participants. }\end{array}$ \\
\hline Test Participants & $\begin{array}{l}\text {-Testing the GSC mobile apps with 5 } \\
\text { tasks. } \\
\text {-Completing a post-test question- } \\
\text { naire. }\end{array}$ \\
\hline
\end{tabular}

Blue Eyes Intelligence Engineering \& Sciences Publication 
Participants: The facilitator invites in one session, ten participants into the testing room. The usability testing facilitator then explained the instructions that needed to be followed by participants. Each individual session lasted for approximately 20 minutes. During the session, the facilitator explained the test session and asked the participants to read the task scenarios and urged them to do the task using android mobile application. After the test session, the facilitator then made the participants to fill out a post-test questionnaire. The table below (Table 2) shows the demographics of participants. Participants in the 20 to 25 age category were 14 in number. Nine (9) of them were females and 5 were males. Of the 14, only 2 had prior experience on the mobile application. Also, only 3 participants each were in the 26 to 30 and 31 to 35 age categories with all participants being females. Participants with experience were only one for the 26-30 category while there was none for the 31-35 age category [26-37].

Table. 2 Demographics

\begin{tabular}{|c|c|c|c|c|}
\hline \multirow{2}{*}{$\begin{array}{c}\text { Number of } \\
\text { participants }\end{array}$} & \multirow{2}{*}{ Age } & \multicolumn{2}{|l|}{ Gender } & $\begin{array}{l}\text { Experienced } \\
\text { Participants }\end{array}$ \\
\cline { 3 - 5 } & & Female & Male & \\
\hline 14 & $20-25$ & 9 & 5 & 2 \\
\hline 3 & $26-30$ & 3 & 0 & 1 \\
\hline 3 & $31-35$ & 3 & 0 & 0 \\
\hline
\end{tabular}

Test Metrics: The usability testing was done to measure 5 metrics as listed below:
i. Time taken to finish task
ii. Time taken to response
iii. Time taken to key-in data
iv. Success on task

v. Number of mistakes made while inputting data

Time taken to finish task, time taken to respond, and time taken to key-in data were metrics used to measure efficiency while success on the tasks and number of mistakes made while inputting data were metrics used to measure effectiveness. Effectiveness is the quality of a software interface that defines the extent at which users achieves their goals with completeness and accuracy on a software interface. Efficiency on the other hand is the quality of a software interface that defines the amount of resource (in terms of mental efforts and time, etc.) expended by users to achieve their goals with completeness and accuracy on a software interface [38-49].

Testing environment: The usability testing was carried out with a laptop per participant to record and capture the metrics along with the facial expression of the participants. The android mobile devices installed a screen recorder with audio, editor and screenshot. One of the most useful recordings the test facilitators captured was a video of screen activities, recording everything on the screen, pages scrolling, clicking links, typing of search terms, and so on. With the recording, the metrics of time taken to finish task, time taken to response, time taken to key-in data, number of mistake made while inputting data and how easy it is to find a function in the mobile application were recorded. Figure 1 illustrates the test environment [50-53].

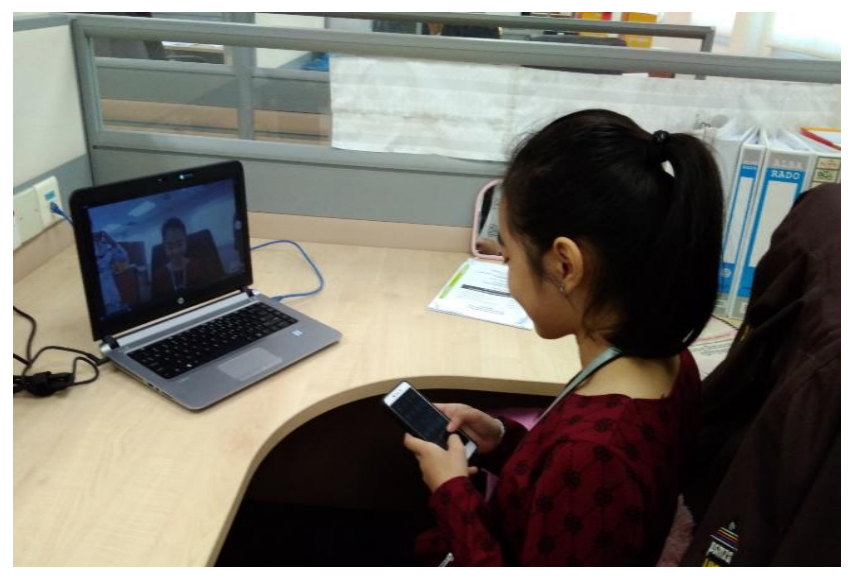

Fig. 1 Testing environment

Test Materials: In addition to the laptops, mobile phones, and the installed applications used. The following are other test materials used in the usability testing:

\section{Test Tasks}

A set of 5 task scenarios were prepared for participants, so that they can use them during the test. The task scenarios were provided based on the services that are offered in the GSC mobile application. The selected tasks include: i) download \& install GSC apps, ii) register \& login, iii) checking on movie list, iv) purchase ticket and v) FastTicket.

\section{Questionnaire}

The post-test questionnaire used had twenty items, divided into seven parts: participants' details, interface, terminology \& application information, learning, application capabilities, general impression and overall reaction. This questionnaire used a 10-point Likert scale.

Test Protocol: During the testing, all participants performed usability testing at the same time and place. All paper materials, such as instructions, task lists and scenarios and checklists were provided and participants were helped freely where necessary while they were testing. Before conducting the test, the facilitator briefed and instructed participants on the conduct of the test. Then a pre-test questionnaire was given to participants to collect their demographic data, prior knowledge and experience. Based on a checklist, users performed each task, and then answered the post-test questionnaire. After the testing, there was a interactive debriefing session. The participants discussed their findings in the session. The topics of discussion and environment were video recorded to enable the participants' responses and behavior to be later analyzed.

Analyzing and preparation of reports: After the debriefing and post-test questionnaire session, the findings were analyzed and report prepared. The report included the scope and severity of problems captured in the test [45-51].

\section{RESULTS AND DISCUSSION}

Generally, all participants found that the GSC cinema mobile application is clear, straightforward and easy to use. However, the test also identified a few minor problems. 
Details per task are as follows:

\section{Task 1: Download and Install GSC application}

1. Seventeen (17) participants successfully downloaded and installed the GSC mobile application in one minute.

2. No participant had problem with this task.

\section{Task 2: Register and Login as a user}

1. Three (3) participants took more than 3 minutes time to validate the registration account email.

2. Participants were confused concerning the advertisement in the front page and the menu list while trying to create account and login.

Task 3: Check on movie listing
1. Four (4) participants were confused and directly clicked on the movie menu list. They were supposed to click on the cinema menu as the task scenario instructed.

\section{Task 4: Purchase ticket(s) and Task 5: FasTicket}

1. No participant had problem doing this task. The task was easy and straightforward.

2. Furthermore, in the analysis, a one sample t-test was conducted and the test mean scores were compared with the population means. All comparisons were significant (see Table 3 ). The test recorded a $100 \%$ success rate as all study participants were able to accomplish and finish their tasks. The other results of the analysis are presented in Table 3 below:

Table. 3 Presentation of t-test Results

\begin{tabular}{|c|c|c|c|c|}
\hline Metric & $\mu$ & Std & p-value & $95 \% \mathrm{CI}$ \\
\hline Time taken to finish task & $12.75 \mathrm{mins}$ & 5.93 & $\begin{array}{c}6.796(9) \\
p=.00\end{array}$ & $(8.5024,16.9876)$ \\
\hline Time taken to key-in data & 5.96 mins & 2.85 & $\begin{array}{c}6.615(9) \\
p=.00\end{array}$ & $(3.9218,7.9982)$ \\
\hline Time taken to respond & $3.52 \mathrm{mins}$ & 4.22 & $\begin{array}{c}2.641(9) \\
\mathrm{p}=.027\end{array}$ & $(0.5050,6.5390)$ \\
\hline Number of mistake while inputting data & .02 & .67 & $\begin{array}{c}4.817(9) \\
\mathrm{p}=.001\end{array}$ & $(0.5410,1.4990)$ \\
\hline
\end{tabular}

As can be seen in Table 3, there were significantly fewer time taken to finish task compared to the population mean time to finish task, $\mathrm{t}(9)=6.796, \mathrm{p}=.00<\alpha=.01,95 \% \mathrm{CI}=$ $(8.5024,16.9876)$. Also, there were significantly fewer time taken to key-in data compared to the population time taken to key-in data, $\mathrm{t}(9)=6.615, \mathrm{p}=.00<\alpha=.01,95 \%=$ $(3.9218,7.9982)$. In addition, the mean test time taken to respond was significantly lesser compared to that of the mean population time to respond, $\mathrm{t}(9)=2.641, \mathrm{p}=.027<\alpha$ $=.05 ; 95 \% \mathrm{CI}=(0.5050,6.5390)$. Finally, there were significantly fewer number of mistakes made while inputting data compared to the population mean number of input data mistakes, $\mathrm{t}(9)=4.817, \mathrm{p}=.001<\alpha=.01,95 \% \mathrm{CI}=(0.5410$, 1.4990). These results implied that the GSC mobile interface is both effective and efficient. This indicates that the GSC mobile application has good usability and provided users an enriching experience.

However, from the observations made by the facilitators, significant verbal comments were made by participants during their attempts to carry out the various tasks. The participants' facial expressions and body language while performing tasks reveal that some of them had some challenges. Features in the GSC app, such as choosing seats and making payment made some of the participants react uneasily and with caution because of their lack of confidence as it had to do with financial matters. Based on observation, most of the participants looked nervous and felt uneasy during the session. This was so even though a short briefing about the test was given to avoid such nervousness. Overall, participants completed their tasks.

\section{CONCLUSION}

Based on the data collection and study result, it can be concluded that the GSC application is effective, efficient and easy to use. GSC application is an objectively usable app. It makes viewing and buying of movie tickets easier.
However, there are still a few features that need to be improved to enhance and increase users satisfaction and experience. The arrangement of menu on the application confuses users on the next step to be followed, especially the inexperienced users.

\section{REFERENCES}

1. Hussain, A, Mkpojiogu, EOC, Yahaya, NB \& Bakar, NZBA (2018), A mobile usability assessment of an m-shopping app. Journal of Advanced Research in Dynamical and Control Systems (JARDCS) 10 (SI), 1212-1217.

2. Gündüz, F \& Pathan, ASK (2013), On the key factors of usability in small-sized mobile touch-screen application. Int. J. Multimed. Ubiquitous Eng, 8(3), 115-138

3. Kaikkonen, A, Kekäläinen, A., Cankar, M, Kallio, T \& Kankainen, A (2005), Usability testing of mobile applications: A comparison between laboratory and field testing. Journal of Usability Studies, 1(1), 4-16.

4. Hussain, A, Mkpojiogu, EOC, Jamalsse, A \& Mohammed, RA (2018), Grab mobile app: a UX assessment on mobile devices. Journal of Ad vanced Research in Dynamical and Control Systems (JARDCS) 10 (SI), 1233-1238.

5. Liu, F (2008), Usability Evaluations on Websites. School of Art \&Design, Wuhan University of Technology, Wuhan, Hubei Province, p: 141 .

6. Dumas, JS \& Redish, J (1999), A practical Guide to Usability Testing. Intellect Ltd, UK, US

7. Srivasta, J, Cooley, R, Deshpande, M \& Tan, PN (2000), Web Usage Mining: Discovery and Application of Web Usage Pattern from Web Data. Department of Computer Science and Engineering, University of Minnesota.

8. Mkpojiogu, EOC, Hussain, A \& Hassan, F (2018), A systematic review of usability quality attributes for the evaluation of mobile learning applications for children. ICAST 2018, AIP Conf. Proc. 2016 , https://doi.org/10.1063/1.5055494

9. Icela, L (2017), Usability evaluation focused on user experience of repositories related to energy sustainability: A Literature Mapping.

10. Nayebi, F, Desharnais, JM \& Abran, A (2012), The state of the art of mobile application usability evaluation, 2012 25th IEEE Can. Conf. Electr. Comput. Eng., 1-4. 
11. Paz, F \& Pow-Sang, JA (2014), Current Trends in Usability Evaluation Methods: A Systematic Review, 2014 7th Int. Conf. Adv. Softw. Eng. Its Appl., pp: 11-15.

12. Hussain, A, Mkpojiogu, EOC \& Suleiman, K (2018), A usability testing of a mobile print shop booking and design application. Journal of Advanced Research in Dynamical and Control Systems (JARDCS) 10 (SI), 1359-1365.

13. Holzinger, A (2005), Usability engineering methods for software developers. Communications of the ACM, 48(1), 71-74.

14. Molich, R, \& Wilson, C (2008), Tips and tricks for avoiding common problems in usability test facilitation. $\mathrm{CHI}^{\prime} 08$ extended abstracts on Human factors in computing systems. ACM, pp: 2379-2382.

15. Hussain, A, Mkpojiogu, EOC, Suleiman, K \& Alhussian, H (2018), A heuristic evaluation of a mobile print and design shopping application. Journal of Advanced Research in Dynamical and Control Systems (JARDCS) 10 (SI), 1457-1462. Buchanan, S, \& Salako, A (2009), Evaluating the usability and usefulness of a digital library. Library Review, 58(9), 638-651.

16. Rubin, J \& Chisnell, D (2008), Handbook of Usability Testing: How to Plan, Design, and Conduct Effective Tests. Canada: John Wiley \& Sons, Inc.

17. Hussain, A, Mkpojiogu, EOC, Abduljabbar, AM \& Almadhagi, AHG (2018). UUM mobile for students: a usability evaluation on two mobile OS platforms. Journal of Advanced Research in Dynamical and Control Systems (JARDCS) 10 (SI), 1514-1519.

18. Gündüz, F \& Pathan, ASK (2012), Usability improvements for touchscreen mobile flight booking application: A case study. 2012 International Conference on Advanced Computer Science Applications and Technologies (ACSAT), IEEE, pp: 49-54.

19. Dillon, A (2002), Beyond usability: process, outcome and affect in human-computer interactions. Canadian Journal of Library and Information Science.

20. Mkpojiogu, EOC \& Hussain, A (2018), Assessing the influence of selfreported requirements importance on the perceived quality of proposed software products. ICAST 2018, AIP Conf. Proc. 2016, 020091, https://doi.org/10.1063/1.5055493

21. Ahmad, N, Boota, MW \& Masoom, AH (2014), Smart Phone Application Evaluation with Usability Testing Approach, J. Softw. Eng. Appl., 7(12), 1045.

22. Brown, ME \& Hocutt, DL (2015), Learning to Use, Useful for Learning: A Usability Study of Google Apps for Education, $J$. Usability Stud., 10 (4), 160-181.

23. Hussain, A, Mkpojiogu, EOC, Isse, AJ \& Mohammed, RA (2018), Grab mobile application: a usability evaluation. ICAST 2018, AIP Conf Proc. 2016, 020054, https://doi.org/10.1063/1.5055456

24. ISO 9241-11 (1998), Ergonomic requirements for office work with visual display terminals (vdts)-part 11: Guidance on usability. ISO Standard 9241-11: 1998. International Organization for Standardization.

25. Hussain, A, Mkpojiogu, EOC, Yahaya, NB \& Bakar, NZBA (2018), A mobile usability assessment of carousell mobile app. ICAST 2018, AIP Conf. Proc. 2016. 020053, https://doi.org/10.1063/1.5055455

26. Bartek, V \& Cheatha, MD (2003), Experience Remote Usability Testing, Part 2: Examine the Benefits and downside of Remote Usability Testing. http://www.mendeley.com/research/experience-remoteusability-testing-part-2-examine-benefits-downside-remote-usabilitytesting/.

27. Hussain, A, Mkpojiogu, EOC, Abduljabbar, AM \& Almadhagi, AHG (2018), A usability evaluation of UUM mobile for students app on IOS and android platforms. ICAST 2018, AIP Conf. Proc. 2016, 020052 https://doi.org/10.1063/1.5055454

28. Chau, P. Cole, M, Massey, AP, Montoya-Weiss, M \& O'Keefe, RM (2002), Cultural differences in consumer's online behaviors. Commun $A C M, 45(10), 45-50$

29. Hussain, A, Mkpojiogu, EOC \& Hassan, F (2018), Usability dimensions and sub-dimensions for the evaluation of m-learning apps for children: A review. International Journal of Engineering \& Technolo gy (IJET) 7 (3.20), 291-295.

30. Forsell, C \& Johansson, J (2010), An heuristic set for evaluation in information visualization. Proceedings of the International Conference on Advanced Visual Interfaces, ACM, pp: 199-206.

31. Krippendorff, K (2004), Content Analysis: An introduction to its methodology, (Sage Publications Inc., United States, 2004).

32. Gehrke, D \& Turban, E (1999), Determinants of successful website design: Relative importance and recommendations for effectiveness, Proc. 32nd Hawaii Int. Conf. System Sciences.

33. Harrison, R, Flood, D \& Duce, D (2013), Usability of mobile applications: Literature Review and Rationale for A New Usability Model, 1-16.
34. Hussain, A \& Mkpojiogu, EOC (2015), An application of the ISO/IEC 25010 standard in the quality-in-use assessment of an online health awareness system, J. Teknol., 77(5) 9-13.

35. El-Gayar, O, Timsina, P, Nawar, N, \& Eid, W (2013), Mobile applications for diabetes self-management: Status and potential, $J$. Diabetes Sci. Technol., 7(1), 247-262.

36. Naismith, L (2004), Literature review in mobile technologies and learning, NESTA Futur. Ser. ; Rep. 11, p: 44

37. Hussain, A, Abd Razak, MNF, Mkpojiogu, EOC \& Hamdi, MMF (2017), UX evaluation of a video streaming application with teenage users. Journal of Telecommunication, Electronic \& Computer Engineering (JTEC), 9 (2-11), 129-131.

38. Naslund, JA, Aschbrenner, KA, Marsch, LA \& Bartels, SJ (2016), The future of mental health care: Peer-To-peer support and social media, Epidemiol. Psychiatr. Sci., 25 (2), 113-122.

39. Hussain, A, Isam, M \& Mkpojiogu, EOC (2017), A UX assessment of a mobile recommender app for household electrical energy savings. Journal of Telecommunication, Electronic \& Computer Engineering (JTEC), 9 (2-11)

40. Joo, S, Lin, S \& Lu, K (2011), A Usability Evaluation Model for Academic Library Websites: Efficiency, Effectiveness and Learnability, J. Libr. Inf. Stud., 9(2), 11-26.

41. Toribio-Guzmán, JM, García-Holgado, A, Pérez, FS, García-Peñalvo, FJ \& Martín, MAF (2016), Study of the Usability of the Private Social Network SocialNet using Heuristic Evaluation, Proc. XVII Int. Conf. Hum. Comput. Interact. - Interacción '16, pp: 1-5.

42. Hussain, A, Mkpojiogu, EOC \& Jasin, NMD (2017), Usability metrics and methods for public transportation applications: a systematic review. Journal of Engineering Science and Technology (JESTEC), Special Issue on ISSC'16, 4, 98-105.

43. Chiang, KP \& Dholakia, RR (2003), Factors Driving Consumer Intention to Shop Online: An Empirical Investigation, Journal of Consumer psychology, 13(1\&2), 177-183.

44. Hussain, A, Isam, M \& Mkpojiogu, EOC (2017), A UX assessment of a mobile recommender app for household electrical energy savings. Journal of Telecommunication, Electronic \& Computer Engineering (JTEC), 9 (2-11)

45. Bangor, A, Kortum, P \& Miller, J (2009), Determining what individual SUS scores mean: Adding an adjective rating scale. Journal of Usability Studies, 4(3), 114-123.

46. Hussain, A, Mkpojiogu, EOC, Musa, J \& Mortada, S (2017), A user experience evaluation of amazon kindle mobile application. Proceedings of the $2^{\text {nd }}$ International Conference on Applied Science and Tech nology (ICAST'17), Kedah, Malaysia. AIP Conference Proceeding 1891 (1), 020060, http://doi.org/10.1063/1.5005393

47. Nielsen, J (1993), Usability Engineering, Academic Press, United States.

48. Hussain, A, Mkpojiogu, EOC, Fadzil, NM \& Hassan, NM (2017), The UX of amila pregnancy on mobile device. Proceedings of the $2^{\text {nd }}$ Inter national Conference on Applied Science and Technology (ICAST'17), Kedah, Malaysia. IP Conference Proceedings 1891 (1), 020061, http://doi.org/10.1063/1.5005394

49. Kiseol, Y \& Hye-Young, K (2012), Mobile shopping motivation: an application of multiple discriminant analysis, International Journal of Retail \& Distribution Management, 40(10), 778-789.

50. Hussain, A, Mkpojiogu, EOC, Abubakar, H \& Hassan, HM (2017), The usability evaluation of mudah.my on mobile device. Proceedings of the $2^{\text {nd }}$ International Conference on Applied Science and Technology (ICAST'17), Kedah, Malaysia. AIP Conference Proceedings 1891 (1), 020058; http://doi.org/10.1063/1.5005391

51. Ferré, X, Juristo, N, Windl, H \& Constantine, L, Usability engineering Usability Basics, IEEE Softw., 18

52. Hussain, A, Mkpojiogu, EOC, Jamaludin, NH \& Moh, STL (2017), A usability evaluation of Lazada mobile application. Proceedings of the $2^{\text {nd }}$ International Conference on Applied Science and Technology (ICAST'17), Kedah, Malaysia. AIP Conference Proceedings 1891 (1), 020059, http://doi.ord/10.1063/1.5005392

53. Limayem, M, Khalifa, M \& Frini, A (2000), What make consumer buy from internet? A Longitudinal study of online shopping. IEEE Transactions on Systems, Man, and Cybernetics-Part A: Systems and $\mathrm{Hu}$ mans, 30(4). 